\title{
Autoradiographic Localization and Biochemical Characterization of Peripheral Type CCK Receptors in Rat CNS Using Highly Selective Nonpeptide CCK Antagonists
}

\author{
D. R. Hill, N. J. Campbell, T. M. Shaw, and G. N. Woodruff \\ Neuroscience Research Centre, Merck Sharp and Dohme Research Laboratories, Harlow, Essex, CM20 2QR, England
}

Two potent and highly selective nonpeptide antagonists, L-365,031 [1-methyl-3-(4-bromobenzoyl)amino-5-phenyl-3H1,4 benzodiazepin-2-one] and ${ }^{3} \mathrm{H}-\mathrm{L}-364,718$ [1-methyl-3-(2indoloyl)amino-5-phenyl-3H-1,4 benzodiazepin-2-one] were used to localize "peripheral" CCK receptors in rat brain. In autoradiographic experiments, L-365,031 displaced ${ }^{25}$ |-Bolton Hunter CCK-8 binding from the interpeduncular nucleus (IPN) $\left(\mathrm{IC}_{50}=7 \times 10^{-8} \mathrm{M}\right)$, the area postrema (AP), and the nucleus tractus solitarius (NTS) without influencing specific binding to other areas, such as the cerebral cortex or the spinal tract of the trigeminal nerve. Desulfated CCK preferentially inhibited ${ }^{125} \mid$-CCK binding to cerebral cortex $\left(\mathrm{IC}_{50}=\right.$ $\left.7 \times 10^{-8} \mathrm{M}\right)$ rather than IPN $\left(\mathrm{IC}_{50}>1 \times 10^{-8} \mathrm{M}\right)$ or AP-NTS. In the medulla the localization of ${ }^{3} \mathrm{H}-\mathrm{L}-364,718$ binding was similar to L-365,031-sensitive ${ }^{125}$-CCK-8 binding and was found in the AP and medial, but not lateral, aspects of the NTS. In membranes prepared from IPN, NTS, and AP, ${ }^{3} \mathrm{H}$ 364,718 binding was of high affinity $\left(K_{d}=0.14 \mathrm{nM}\right)$, saturable $\left(B_{\max }=20 \mathrm{fmol} / \mathrm{mg}\right.$ protein), and inhibited by compounds previously shown to act at pancreatic CCK receptors. The receptors labeled by ${ }^{3} \mathrm{H}-364,718$ were modulated by guanyl nucleotide, which reduced agonist affinity 10 -fold without affecting antagonist binding. The localization and high density of CCK receptors in AP and NTS suggest that these receptors may play an important role in processing sensory afferent information.

Cholecystokinin (CCK) is present in high concentrations in the mammalian CNS (Vanderhaeghen et al., 1975, 1980; Dockray, 1976; Innis et al., 1979). Indeed, as the sulfated octapeptide (sCCK-8), it is found in certain brain regions in higher concentrations than any other neuropeptide (see Crawley, 1985, for review). The distribution of sCCK-8 throughout the CNS, its localization in neuronal perikarya and nerve fibers, and its coexistence with other putative neurotransmitters (Hökfelt et al., 1980; Greenwood et al., 1981; Vanderhaeghan et al., 1981; Kubota et al., 1983; Hamill et al., 1984) suggest that this peptide may act as either a neurotransmitter or a neuromodulator. Additionally, the demonstration of binding sites with high affinity for $\mathrm{sCCK}-8$ and related peptide fragments throughout the brain further supports the notion that $\mathrm{SCCK}-8$ might be considered as an important mediator of information transfer between neurons.

\footnotetext{
Received Jan. 23, 1987; accepted Feb. 23, 1987.

Correspondence should be addressed to D. R. Hill, Neuroscience Research Centre, Merck Sharp and Dohme Research Laboratories, Terlings Park, Eastwick Road, Harlow, Essex, CM20 2QR, England.

Copyright $\odot 1987$ Society for Neuroscience 0270-6474/87/092967-10\$02.00/0
}

Biochemical measurements of the affinity of CCK fragments at brain CCK receptors have shown that these differ in their pharmacological specificity when compared with CCK receptors in peripheral organs such as the pancreas or gallbladder (Innis and Snyder, 1980; Saito et al., 1980). For example, "peripheral" CCK receptors display lower affinity for desulfated CCK-8 and gastrin than do "central" CCK receptors found in the brain. Despite such differences between receptors in anatomically separate tissues, those within the CNS have generally been considered as being homogeneous, with no evidence of subtypes in different brain regions. Recently, however, Moran and colleagues (1986) reported that CCK rcceptors in the arca postrcma (AP), the nucleus tractus solitarius (NTS), and the interpeduncular nucleus (IPN) display relatively low affinity for desulfated CCK and may therefore represent "peripheral" type CCK receptors despite their location in central nervous tissue.

Recent developments in our laboratories have yielded a number of highly potent nonpeptide CCK-receptor antagonists that are selective for peripheral CCK receptors (Chang and Lotli, 1986; Evans et al., 1986). As such, these compounds provide very specific probes for determining whether peripheral type CCK receptors do exist in areas of mammalian brain. The present report describes the use of 2 such selective CCK antagonists in demonstrating the existence of $\mathrm{CCK}$ receptors in rat brain which resemble those in the periphery. In the first part of the study, autoradiography was employed to visually demonstrate these sites, with 2 different approaches to detection: first, indirectly, by labeling receptors using ${ }^{125}$ I-Bolton Hunter CCK-8 ( $\left.{ }^{125} \mathrm{I}-\mathrm{BH}-\mathrm{CCK}\right)$ and displacing with an unlabeled antagonist L-365,031 [1-methyl-3-(4-bromobenzoyl)amino-5-phenyl- ${ }^{-} \mathrm{H}$ 1,4-benzodiazepin-2-one], which shows high selectivity for peripheral CCK receptors (Chang and Lotti, personal communication); second, by direct visualization using a tritium-labeled antagonist of even greater selectivity L-364,718 [1-methyl-3-(2indoloyl) amino-5-phenyl-3H-1,4-benzodiazepin-2-one] (Chang and Lotti, 1986; Chang et al., 1986a). Furthermore, the high affinity and selectivity of ${ }^{3} \mathrm{H}-\mathrm{I}-364,718$ has permitted us to characterize these receptors using membrane preparations. Our results suggest that the CCK receptors localized in the AP, NTS, and IPN of rat brain are of the peripheral type, termed CCK-A receptors by Moran et al. (1986).

\section{Materials and Methods}

Autoradiography

Brains were removed from male Sprague-Dawley rats (200-250 gm) and rapidly frozen. Sections $10 \mu \mathrm{m}$ thick were cut on a cryostat and then mounted onto glass slides. The sections were allowed to dry and were stored at $-20^{\circ} \mathrm{C}$ until required. On the day of use, sections were 


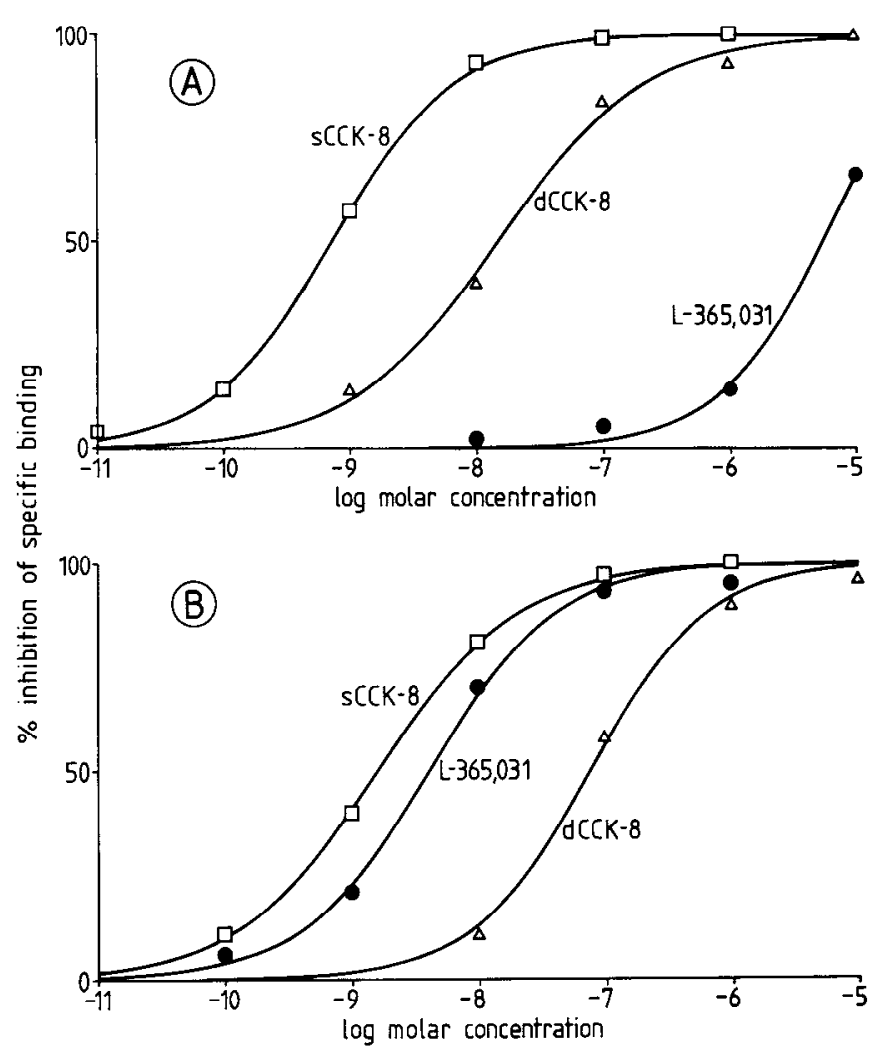

Figure 1. Inhibition of ${ }^{125} \mathrm{I}-\mathrm{BH}-\mathrm{CCK}$ binding to $(A)$ guinea pig brain and $(B)$ rat pancreas by sulfated CCK-8 $(s C C K-8)$, desulfated CCK -8 $(d C C K-8)$, and $\mathrm{L}-365,031$. Membrane homogenates were incubated with $0.1 \mathrm{nM}^{125}$ I-BHCCK-8 for $120 \mathrm{~min}$ at room temperature alone or with increasing concentrations of test compound. Nonspecific binding was determined by $1 \mu \mathrm{M}$ SCCK-8, which was subtracted from total to give the specific portion of binding. Data are mean values from 2 experiments. L-365,031 displayed 1000-fold higher affinity for CCK receptors in the pancreas than in the brain. In contrast, desulfated CCK-8 showed a lower degree of selectivity for central receptors relative to $\mathrm{SCCK}$, on the order of 2- to 10 -fold.

thawed and then incubated in an assay buffer containing either ${ }^{125} \mathrm{I}-$ CCK-8 labeled with Bolton and Hunter reagent (0.6 nM; Amersham International) or ${ }^{3} \mathrm{H}-\mathrm{L}-364,718$ (5 nM; prepared by Dr. Avery Rosegay of MSD Laboratories, Rahway, NJ). Sections were incubated either in the presence of ligand alone or with varying amounts of unlabeled compound. The composition of the assay buffer for all incubations was 20 mм HEPES (pH 6.5), $5 \mathrm{~mm} \mathrm{MgCl}_{2}, 150 \mathrm{~mm} \mathrm{NaCl}, 1 \mathrm{~mm}$ EGTA, and $0.025 \%$ bacitracin. The incubation was allowed to proceed for 60 min at room temperature, after which the sections were washed 4 times for 2 min in fresh buffer and then dried in a stream of air. Autoradiographs were generated by apposing sections to LKB-Ultrofilm for $7 \mathrm{~d}$ (for ${ }^{125}$ I-CCK-8) or 8 weeks (for ${ }^{3} \mathrm{H}-\mathrm{L}-364,718$ ). The resulting negatives were analyzed using a Quantimet 920 image analyzer (Cambridge Instruments), and calibration was by means of brain paste standards prepared according to Clark and Hall (1986).

In order to verify the localization of binding in sections of medulla, sections labeled with ${ }^{25} \mathrm{I}$-CCK were apposed for $7 \mathrm{~d}$ to coverslips that had been dipped in Ilford K5 emulsion. These were then developed, fixed, and washed several times before allowing them to dry. The tissue sections were stained using cresyl fast violet and the coverslips fixed in position with DPX mounting medium. The slides were viewed under normal illumination for histological examination and under dark-field illumination for visualization of silver grains.

\section{Tissue preparations}

Guinea pig cortex. The brains were removed from adult guinea pigs $(300-400 \mathrm{gm})$ and the cortex dissected free of other tissue. This was then homogenized in $20 \mathrm{vol}$ of ice-cold $0.32 \mathrm{M}$ sucrose using a glass homogenizer and Teflon pestle. The homogenate was centrifuged at $1000 \times g$ for $10 \mathrm{~min}$, after which the superantant was recentrifuged at $48,000 \times g$ for $20 \mathrm{~min}$. The resulting pellet was resuspended in standard assay buffer (SAB) (20 mM HEPES, pH 6.5, $5 \mathrm{~mm} \mathrm{MgCl}_{2}, 150 \mathrm{~mm} \mathrm{NaCl}$, $1 \mathrm{~mm}$ EGTA, and $0.025 \%$ bacitracin) at a tissue concentration of $1 \mathrm{gm}$ original wet weight to $40 \mathrm{ml}$ assay buffer.

Rat pancreas. The pancreas was removed from male Sprague-Dawley rats and homogenized for $15 \mathrm{sec}$ in $20 \mathrm{vol}$ of ice-cold buffer comprising $10 \mathrm{~mm}$ HEPES, pH 7.4, plus $0.01 \%$ soybean trypsin inhibitor (SBTI) using a Polytron homogenizer. The tissue was centrifuged for $15 \mathrm{~min}$ at $48,000 \times g$ and the pellet resuspended in SAB supplemented with $0.01 \%$ SBTI and $0.2 \%$ BSA. The final tissue concentration in the assay was $1 \mathrm{gm}$ original wet weight of tissue to $4000 \mathrm{ml}$ of assay buffer.

Rat, $A P, N T S$, and IPN. After removal of the brains from SpragueDawley rats, a $2 \mathrm{~mm}$ slice of tissue containing the IPN was cut just caudal to the hypothalamus using a pair of parallel-mounted razorblades. Similarly, a slab of tissue was cut from the medulla, $2 \mathrm{~mm}$ rostral to the beginning of the obex. From each of these slices, the appropriate area was dissected away from surrounding tissue, and for each assay the combined tissue from 13 rats was used. After dissection, the tissue was transferred immediately and maintained in ice-cold Krebs-Henseleit prior to homogenization in $10 \mathrm{~mm}$ HEPES, pH 7.4, with a glass homogenizer fitted with a Teflon pestle. The tissue homogenate was then centrifuged for $15 \mathrm{~min}$ at $48,000 \times \mathrm{g}$, and the pellet was finally resuspended in $\mathrm{SAB}$ at a tissue concentration of approximately $10 \mathrm{mg}$ original wet weight $/ \mathrm{ml}$ buffer.

\section{Binding assays}

The protocol for each binding assay was essentially the same, with only details differing. Aliquots of tissue were incubated at $20^{\circ} \mathrm{C}$ for either 60 min with ${ }^{3} \mathrm{H}-\mathrm{L}-364,718(0.2-0.3 \mathrm{~nm}$ with AP, NTS, and IPN) or 120 min with ${ }^{125} \mathrm{I}-\mathrm{BH}-\mathrm{CCK}(0.1 \mathrm{nM}$ with guinea pig brain or rat pancreas). Test compounds were included over a range of concentrations, and

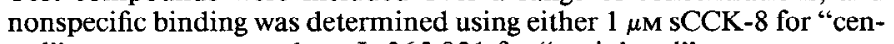

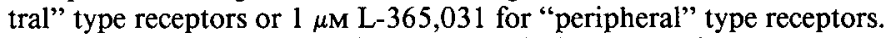
Saturation analysis was performed in a similar way, with the concentration of ligand being increased from $0.02 \mathrm{~nm}$ upwards. After each incubation, assays were terminated by filtration onto Whatman $\mathrm{GF} / \mathrm{C}$ filters using a Brandel cell harvester, and the filters were washed a further 4 times with $3 \mathrm{ml}$ of $20 \mathrm{~mm}$ HEPES, $\mathrm{pH} 6.5$. The radioactivity associated with the filters was then counted using either a gamma-counter or liquid scintillation counter.

\section{Materials}

${ }^{125}$ I-Bolton Hunter CCK was from Amersham International U.K. (specific activity $\sim 2000 \mathrm{Ci} / \mathrm{mmol}$ ). ${ }^{3} \mathrm{H}( \pm) \mathrm{L}-364,718$ (specific activity, 67.4 $\mathrm{Ci} / \mathrm{mmol}$ ) was synthesized by Dr. A. Rosegay of M.S.D. Laboratories (Rahway, NJ), and L-365,031 was prepared by M.S.D. Laboratories (West Point, PA). CCK-8 and related peptides were purchased from Bachem U.S.A. or CRB U.K. (R) and (S) Tifluadom were synthesized by Dr. M. Bock (M.S.D., West Point, PA). All other reagents were of analytical grade and purchased from commercial sources.

\section{Results}

${ }^{125} I-C C K-8$ binding in rat pancreas and guinea pig brain

Figure 1 shows the selectivity of the antagonist L-365,031 for CCK receptors in pancreas versus cerebral cortex. In agreement with Chang and Lotti (1986), the degree of selectivity shown by this compound was on the order of 1000 -fold in favor of the pancreatic receptor $\left(\mathrm{IC}_{50}=4 \times 10^{-9} \mathrm{M}\right)$ compared with sites present in the cortex $\left(\mathrm{IC}_{50}=5 \times 10^{-6} \mathrm{M}\right)$. Desulfated CCK displayed a much smaller degree of selectivity, having an affinity about 10 -fold less potent than the sulfated form against guinea pig brain binding $\left(\mathrm{IC}_{50} \mathrm{sCCK}=8 \times 10^{-10} \mathrm{M}, \mathrm{IC}_{50} \mathrm{dCCK}=1 \times\right.$ $\left.10^{-8} \mathrm{M}\right)$ and 70 -fold less against pancreatic binding $\left(\mathrm{IC}_{50} \mathrm{sCCK}=\right.$ $\left.1 \times 10^{-9} \mathrm{M}, \mathrm{IC}_{50} \mathrm{dCCK}=8 \times 10^{-6} \mathrm{M}\right)$.

\section{Autoradiography in rat brain}

In light of these data, a series of autoradiographic experiments were performed to determine the ability of L-365,031 and dCCK 


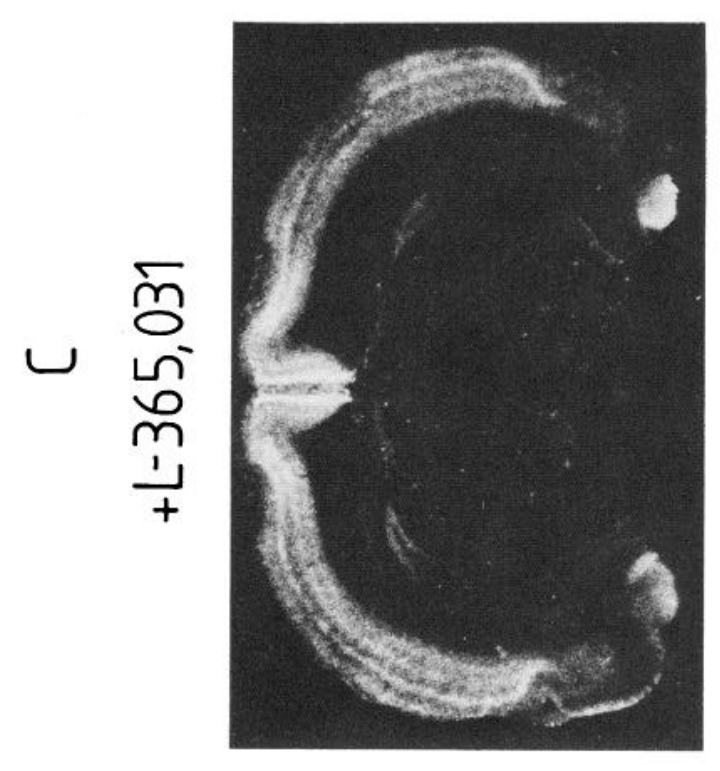

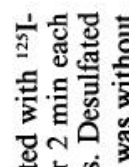

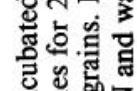

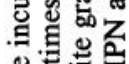

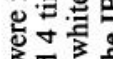

政完

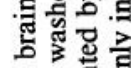

氙密总。

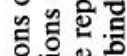

记

约

लि 등

瓷论

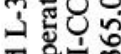

동

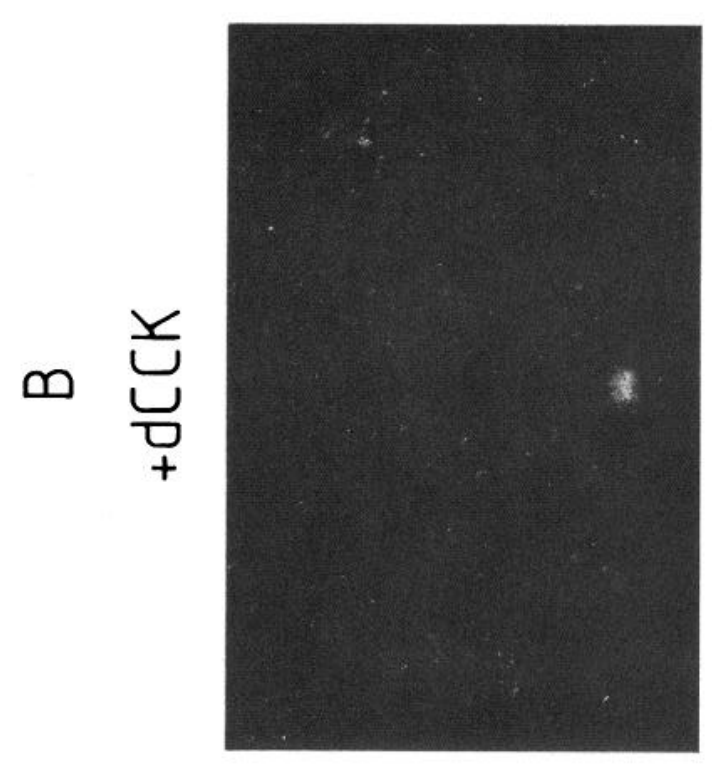

넝 멸

년뎡

䆛焉

青短

ชิ

s. 8

实要

政

둥

×ํํㄹ

당 융 대

현 긍.유

을

응을

등

论

엉의

1 政

㖊

毒要

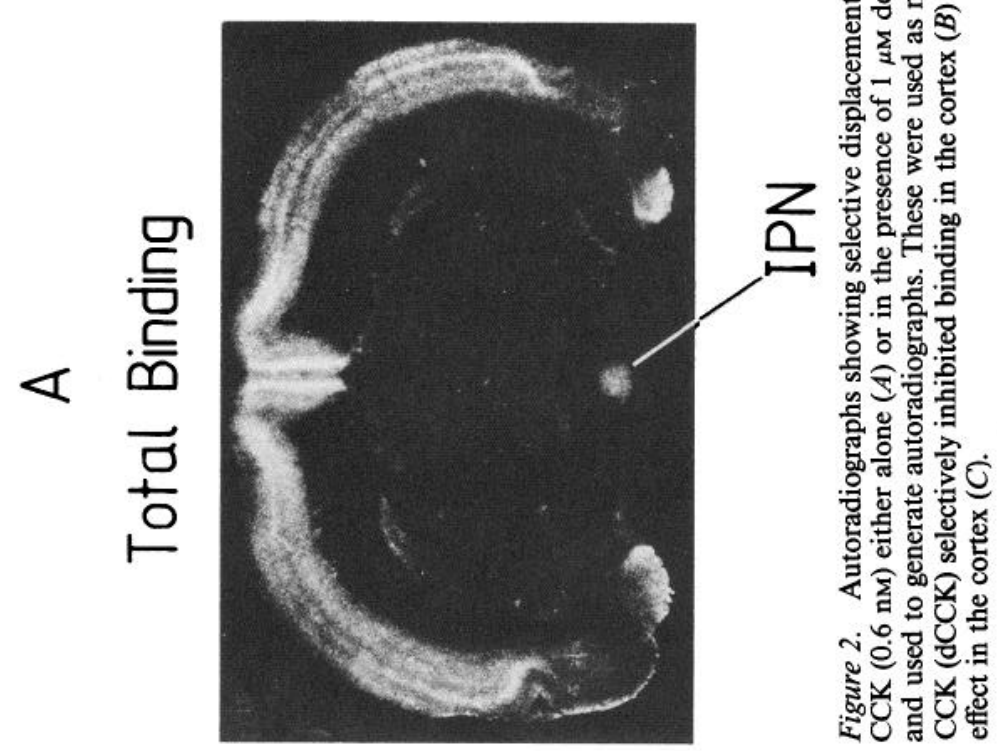




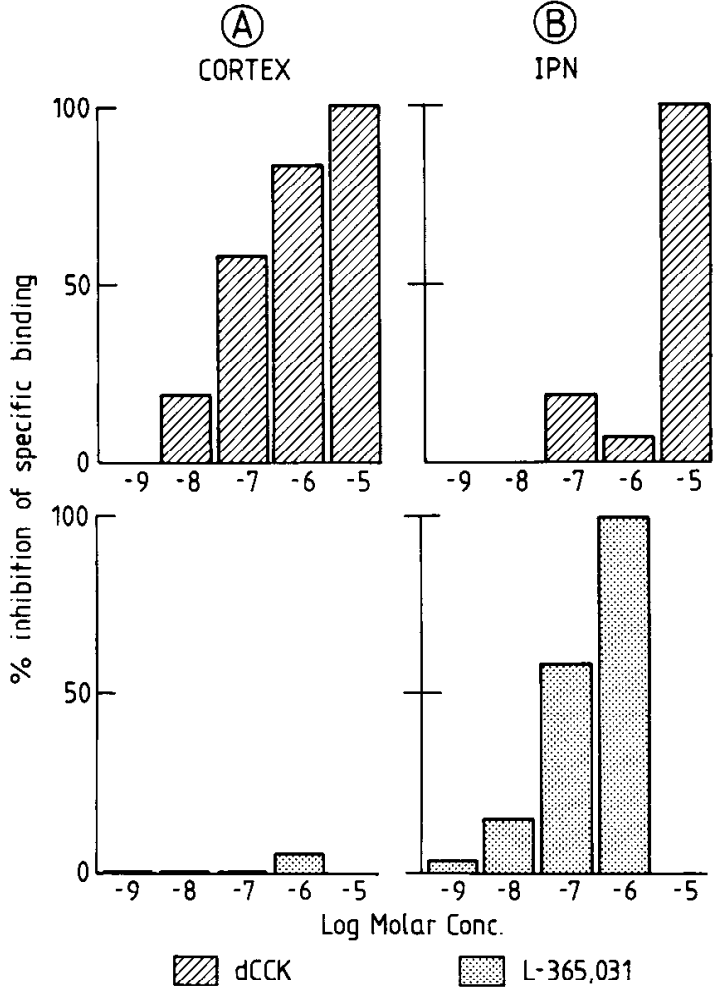

Figure 3. Selective inhibition of specific ${ }^{25}$ I-Bolton-Hunter CCK-8 binding from sections of rat brain containing cortex and interpeduncular nucleus by desulfated CCK $(d C C K)$ and L-365,031. Pairs of sections $10 \mu \mathrm{m}$ thick were incubated for $60 \mathrm{~min}$ with $0.6 \mathrm{nM}{ }^{125}$ I-BHCCK, either alone or in the presence of the indicated concentrations of dCCK or L-365,031. After development of the autoradiographs, the density of binding in the cerebral cortex and IPN was measured using a Quantimet 920 image analyzer. Nonspecific binding was determined by $10^{-6} \mathbf{M}$ CCK-8, which was subtracted from total to give the specific portion. Desulfated CCK displayed greatly affinity for CCK receptors in the cortex than IPN, whereas L-365,031 failed to inhibit binding to cortical sites at concentrations that blocked binding in the IPN. Data are mean values from 2 (L-365,031) or 3 (dCCK) separate experiments.

to displace ${ }^{125} \mathrm{I}$-CCK binding from CCK receptors in cortex and IPN. Figure 2 shows an example of inhibition of ${ }^{125}$ I-CCK binding to coronal sections of rat brain by dCCK $\left(10^{-6} \mathrm{M}\right)$ and $\mathrm{L}-365,031\left(10^{-6} \mathrm{M}\right)$. In addition, Figure 3 presents a quantitative estimate of the degree of inhibition produced by each compound in the IPN and cortex. L-365,031 failed to inhibit binding by more than $10 \%$ in the cerebral cortex at concentrations that were found to be maximally effective in pancreas binding assays (compare Figs. 3 and $1 B$ ). In the IPN, however, L-365,031 produced a dose-dependent reduction in specific ${ }^{125}$ I-CCK binding (Fig. $3 B$ ). The data shown in this figure were fitted by a single hyperbolic function, which yielded an $\mathrm{IC}_{50}$ value of $6.6 \times$ $10^{-8} \mathrm{M}$ for L-365,031, together with a Hill coefficient of 1.00 . By contrast, dCCK displayed greater affinity for receptors in the cortex than in the IPN (Fig. 3), thus agreeing with the observations of Moran et al. (1986). An $\mathrm{IC}_{50}$ value of $7 \times 10^{-8} \mathrm{M}$ (Hill slope, 0.74) was obtained for the data shown, which is close to that found in guinea pig cortex (see above) and that determined autoradiographically $\left(2 \times 10^{-8} \mathrm{M}\right)$ for $\mathrm{dCCK}$ by Moran and colleagues (1986).

Another series of experiments was performed to determine the localization of ${ }^{125} \mathrm{I}-\mathrm{CCK}$ binding sites in hindbrain, and the sensitivity of these sites to L-365,031. Figures 4 and 5 show autoradiographs of rat medulla made using emulsion-coated coverslips or LKB-Ultrofilm, respectively. These sections were taken at approximately bregma $-14 \mathrm{~mm}$ according to the atlas of Paxinos and Watson (1982). Specific ${ }^{125}$ I-CCK binding was localized principally to the regions of the area postrema, the nucleus tractus solitarius and also to the spinal tract of the trigeminal nerve $(\mathrm{Sp} 5)$. The presence of L-365,031 inhibited binding in the AP but failed to modify binding to the trigeminal nerve tract (Fig. $5 A$ ). Sulfated CCK-8 itself displaced binding to AP, NTS, and Sp5 (data not shown).

The density of binding in the area postrema and medial NTS increased progressively in a rostral direction but remained sensitive to inhibition by L-365,031 (Figs. $4, B, C ; 5, B, C$ ). However, binding in the lateral aspects of the NTS was refractory to the antagonist (Figs. $4, E, F ; 5 D$ ), suggesting that these sites are of the classical brain type.

L-364,718 displays even greater affinity and selectivity for peripheral CCK receptors than does L-365,031 (Chang and Lotti, 1986), and it has been used in tritiated form to label pancreatic CCK receptors directly (Chang et al., 1986a). We have therefore used this compound in autoradiographic experiments to directly label peripheral CCK receptors present in caudal regions of rat brain.

Specific binding of ${ }^{3} \mathrm{H}-\mathrm{L}-364,718$ in the rat medulla was localized exclusively to regions of the AP and medial aspects of the NTS (Fig. 6). Neither the spinal tract of the trigeminal nerve nor lateral aspects of the NTS were labeled by the radioligand, agreeing with the pattern of displacement seen with ${ }^{125}$ I-CCK and L-365,031 (compare Figs. 5 and 6). In more rostral sections of medulla, bilateral areas of relatively heavy labeling could be detected, which represented binding in the medial nucleus of the NTS (Fig. 6, $C, D$ ), but lateral aspects of the NTS were not labeled by ${ }^{3} \mathrm{H}-\mathrm{L}-364,718$ (compare Figs. $5 D$ and $6 D$ ).

\section{${ }^{3} \mathrm{H}-\mathrm{L}-364,718$ binding to AP, NTS, and IPN membranes}

The extremely high affinity and selectivity of ${ }^{3} \mathrm{H}-\mathrm{L}-364,718$ for peripheral type $\mathrm{CCK}$ receptors also allowed this compound to be used as a radioligand to characterize "peripheral" sites present in brain using a more convenient membrane binding assay. For this purpose, the AP, NTS, and IPN were dissected and used to prepare a crude membrane preparation.

Binding of ${ }^{3} \mathrm{H}-\mathrm{L}-364,718$ to membrane fragments prepared from AP, NTS, and IPN was both saturable and of very high affinity, with maximum binding capacity $\left(B_{\max }\right)$ of $20.3 \pm 3.9$ $\mathrm{fmol} / \mathrm{mg}$ protein $(n=3)$ and dissociation constant $\left(K_{d}\right)$ of 0.14 $\mathrm{nM}\left(\mathrm{p} K_{d}=9.58 \pm 0.22, n=4\right)$. At concentrations used for displacement studies $(0.2-0.3 \mathrm{nM})$, the specific portion of binding represented between $50-60 \%$ of total binding and was highly reproducible between assays. Binding was displaced by a variety of CCK-related peptide fragments and Table 1 shows mean $\mathrm{pIC}_{50}$ values for these. Sulfated CCK- 8 was the most potent peptide tested $\left(\mathrm{pIC}_{50}=7.8 \pm 0.08\right)$, being equipotent with the nonpeptide antagonist L-365,031 $\left(\mathrm{pIC}_{50}=7.9 \pm 0.3\right)$. Desulfated $\mathrm{CCK}$ was about 100 times less potent than the sulfated octapeptide. Gastrin, CCK-4, and CCK-6 were essentially inactive as inhibitors of binding $\left(\mathrm{pIC}_{50}<4.0\right)$. The opiate agonist tifluadom, which possesses a benzodiazepine structure and has been shown to have antagonist activity at peripheral CCK receptors in pancreas and gallbladder (Chang et al., 1986b), was also active at central CCK receptors labeled by ${ }^{3} \mathrm{H}-\mathrm{L}-364,718$.

CCK receptors in pancreatic membranes have been shown to be sensitive to modulation by guanyl nucleotides such as GTP 

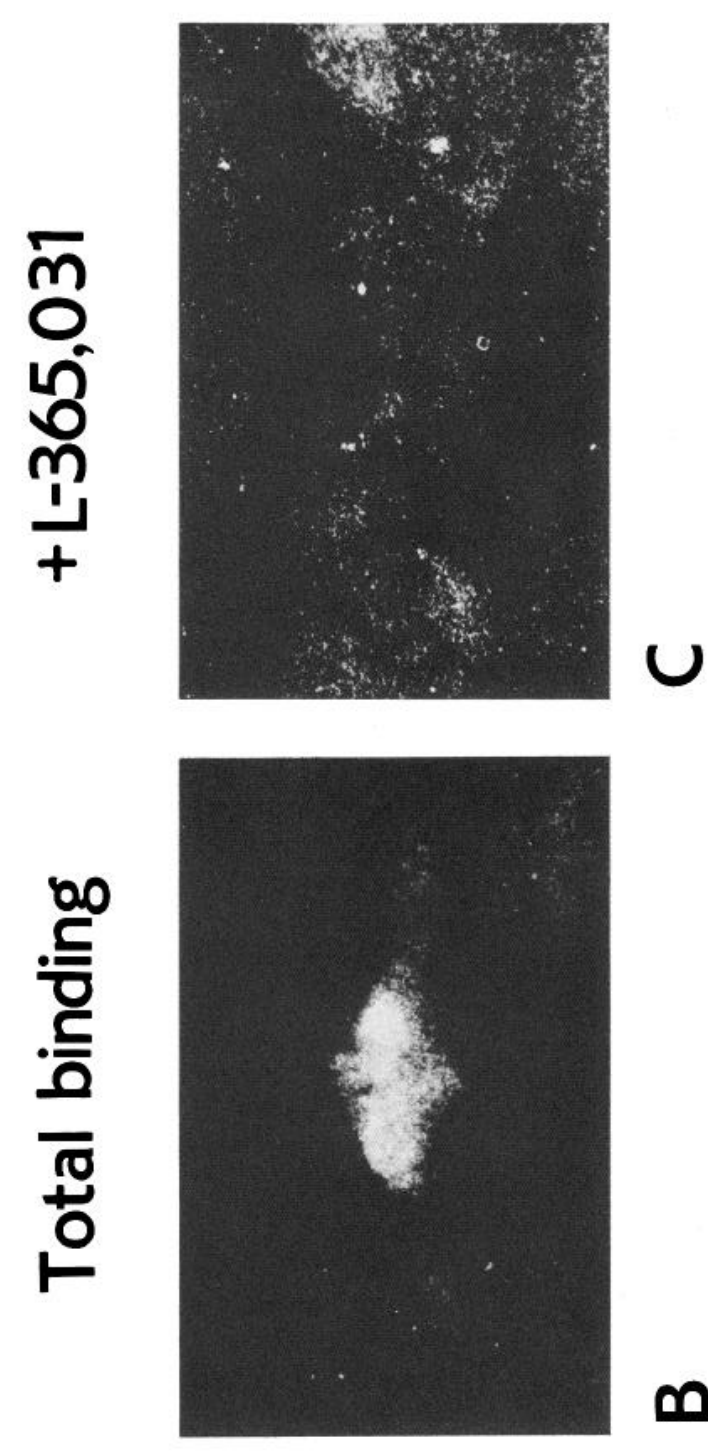

$\infty$
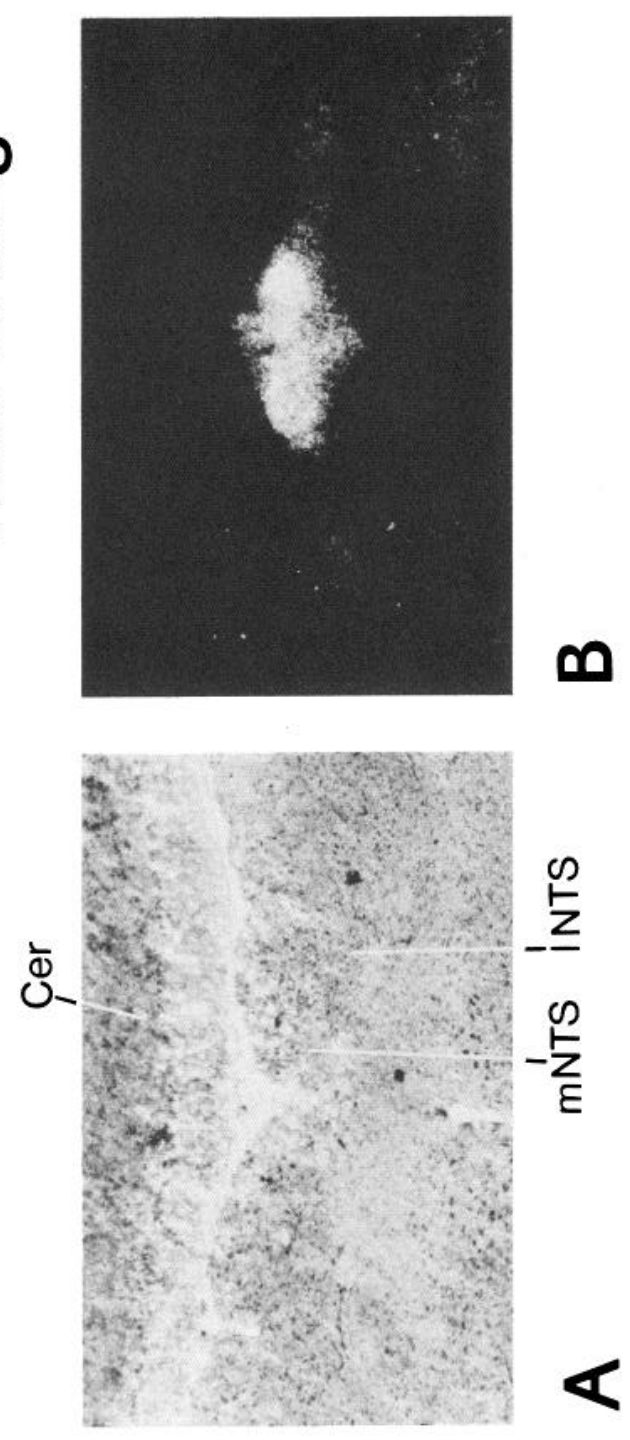

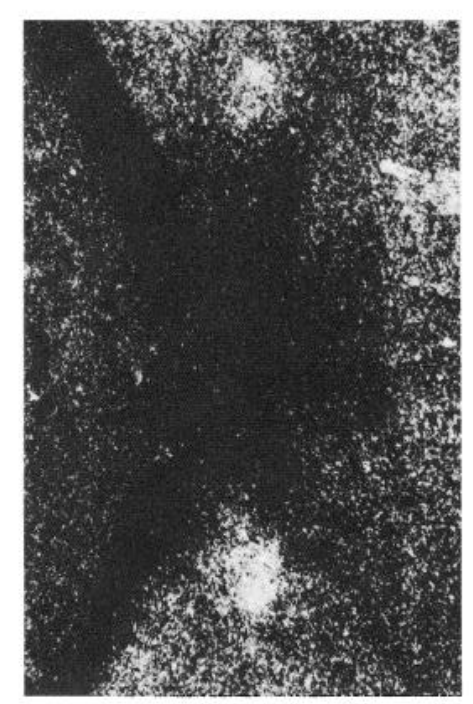

u

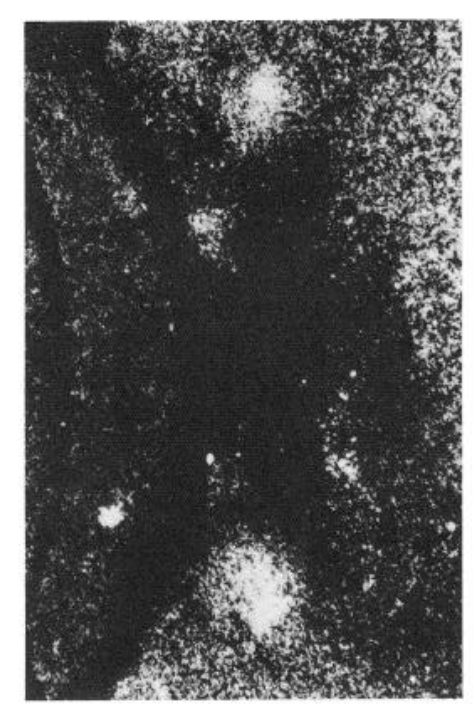

U

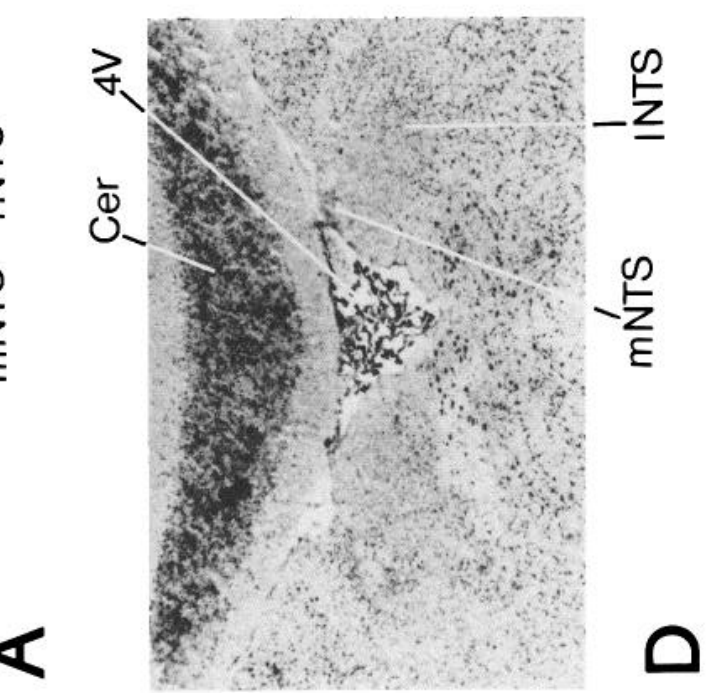

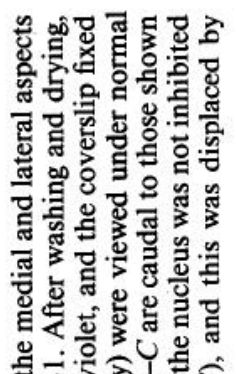

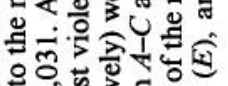
on

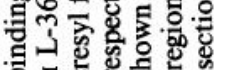
₹

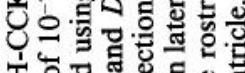

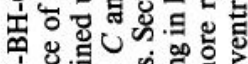
安

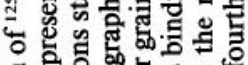

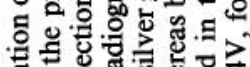

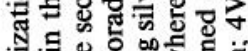
정 政

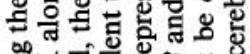

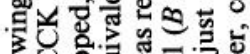
o के 政 政

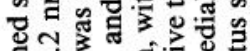
管

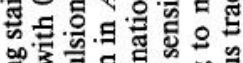
on 3 달

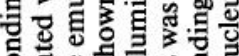
응 究 8.

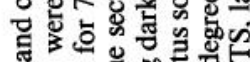

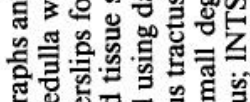

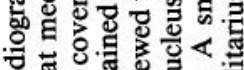

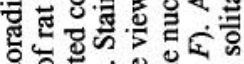

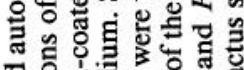

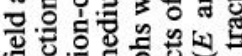
过 秀 色 $\mathrm{b}^{\circ}$ 응 说: E

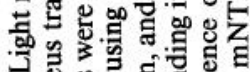

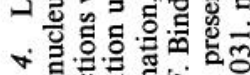

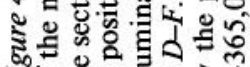

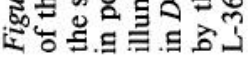




\section{Total Binding}
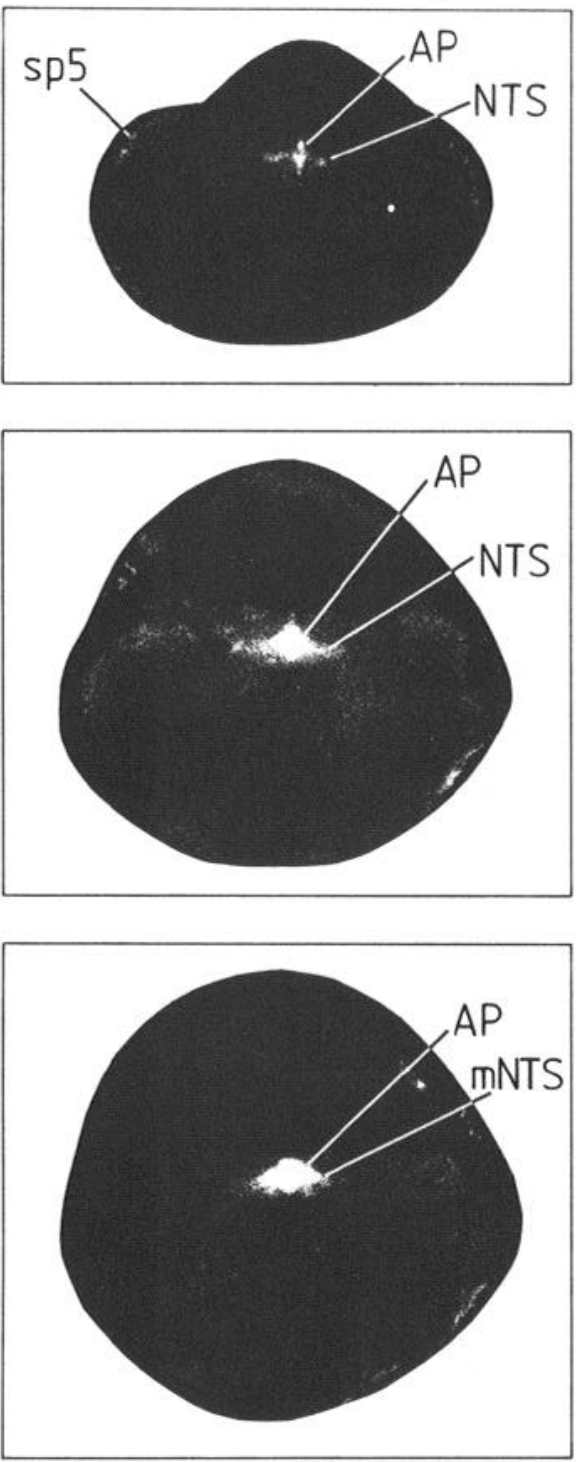
CCK-8 binding to sections of rat medulla and its displacement by $10^{-7} \mathrm{M}$ $\mathrm{L}-365,031$. Sections $(10 \mu \mathrm{m})$ of rat medulla were incubated for $60 \mathrm{~min}$ with $0.6 \mathrm{~nm}{ }^{125} \mathrm{I}-\mathrm{BH}-\mathrm{CCK}$ alone or in the presence of $10^{-7} \mathrm{M} \mathrm{L}-365,031$. After washing and drying, the sections were apposed to LKB Ultrofilm for $6 \mathrm{~d}$ for generation of autoradiographs. On these photographs, the binding of ${ }^{125} \mathrm{I}-\mathrm{BH}$ CCK- 8 is represented by white grains. Specific binding was localized to the area postrema $(A P)$, the nucleus tractus solitarius (NTS), and spinal tract of the trigeminal nerve ( $s p 5)$. Binding in all regions was displaced by $10^{-6} \mathrm{M} \mathrm{SCCK}$ 8. L-365,031 inhibited binding to the AP and medial aspects of the NTS (mNTS) $(A-C)$ but failed to displace binding in either $\operatorname{sp} 5(A)$ or lateral NTS $($ INTS) $(D)$.

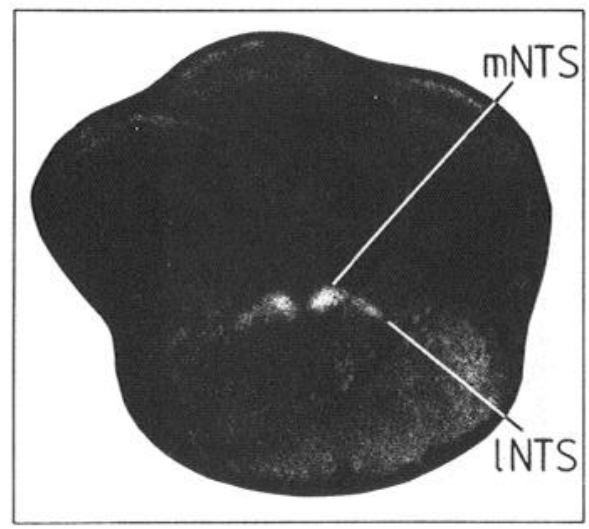

$+L-365,031$

A

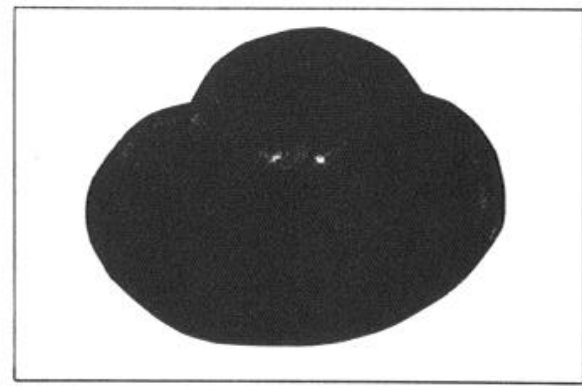

B

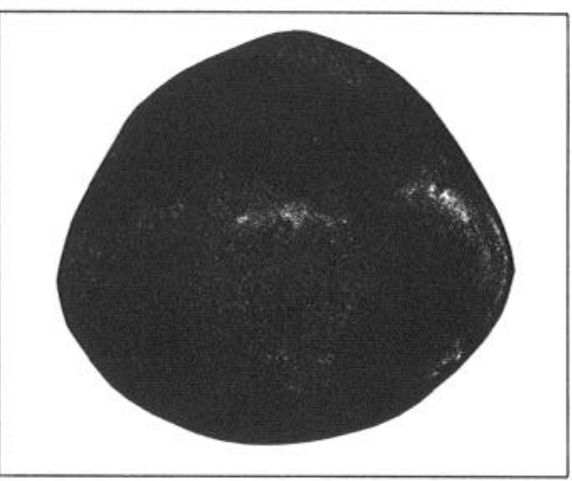

C
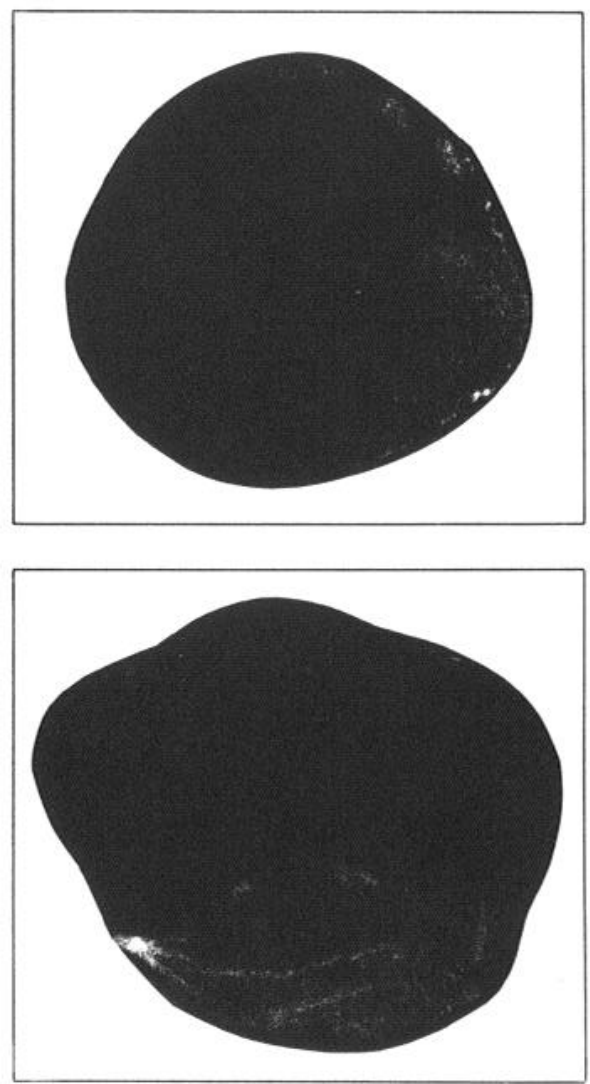

and its more stable analogs (Innis and Snyder, 1980). To determine whether the binding sites present in the AP and IPN also shared this property, the effects of $100 \mu \mathrm{M} \mathrm{GppNHp}$ on ${ }^{3} \mathrm{H}-$ 364,718 binding and on the affinity of CCK as an inhibitor of binding were determined.
The inclusion of GppNHp in the assay medium had no effect on the binding of the antagonist itself. However, the affinity of sCCK-8 for the binding sites was reduced by approximately an order of magnitude from $\mathrm{pIC}_{50}=7.7 \pm 0.03$ under control conditions to $\mathrm{pIC}_{50}=6.5 \pm 0.12$ in the presence of $\mathrm{GppNHp}$ 


\section{Total Binding}
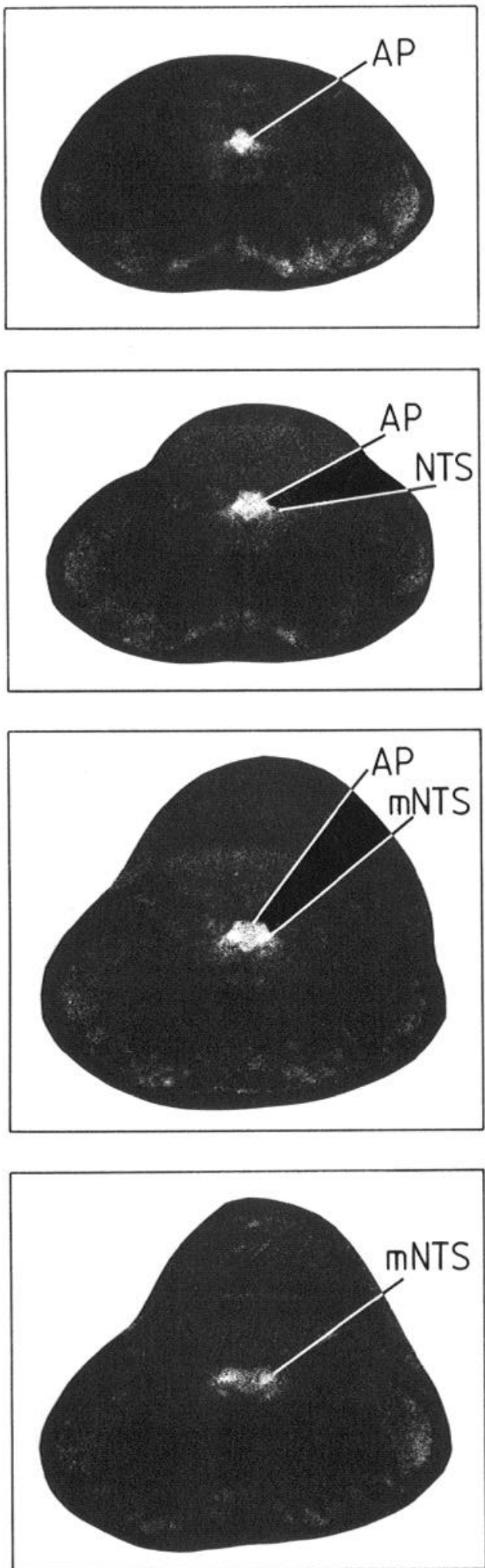

$+L-365,031$

A
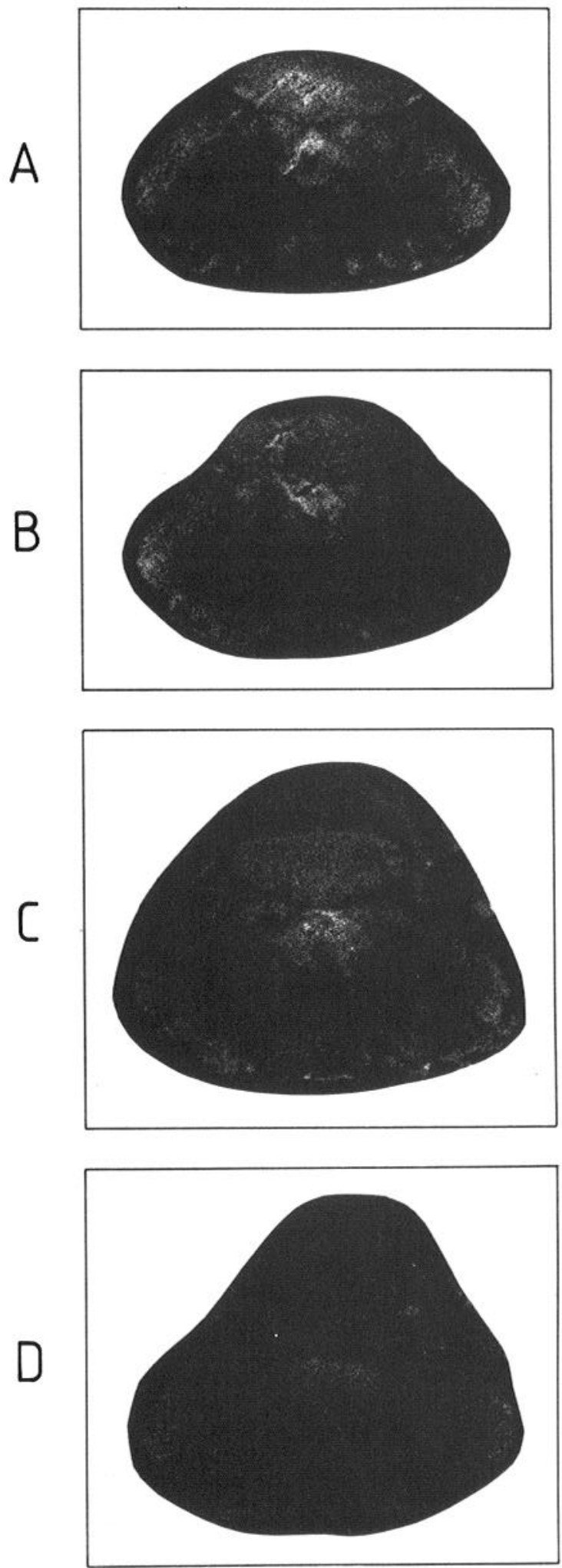

Figure 6. Localization of ${ }^{3} \mathrm{H}-\mathrm{L}-364,718$ binding to sections of rat medulla. Sections $(10 \mu \mathrm{m})$ of rat medulla were incubated either with 5 nM ${ }^{3} \mathrm{H}-\mathrm{L}-364,718$ alone or in the presence of $10^{-7} \mathrm{M} \mathrm{L}-365,031$. After washing and drying, the sections were apposed to LKB Ultrofilm for generation of autoradiographs. ${ }^{3} \mathrm{H}-\mathrm{L}-364,718$ binding is shown by white grains. Binding of ${ }^{3} \mathrm{H}-\mathrm{L}-364,718$ that was displaceable by $\mathrm{L}-365,031$ or CCK (10-6 M) was localized to the area AP and medial portions of the NTS $(A$ and $B)$. Bilateral areas of relatively heavy labeling were localized to the medial LTS ( $m N T S$ ), but no displaceable binding could be detected in the spinal tract of the trigeminal nerve or lateral aspects of the NTS. Compare with Figures $4 D-F$ and $5 D$, for instance. 


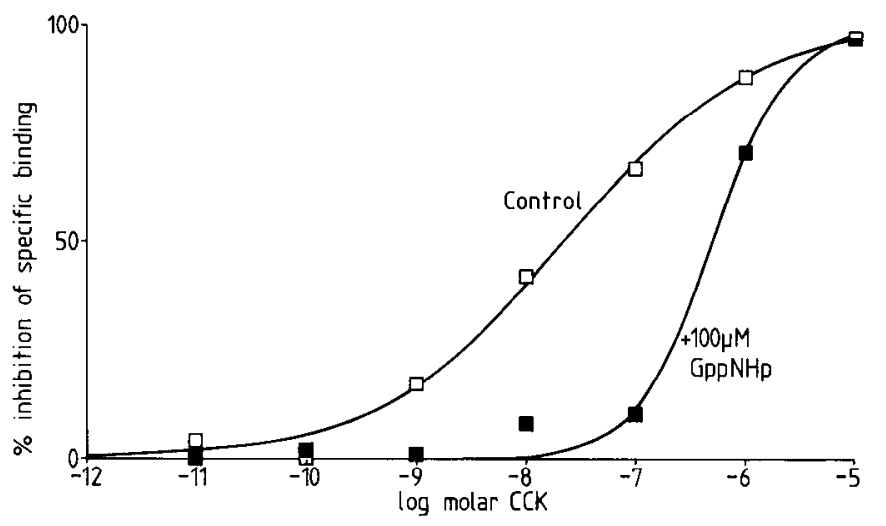

Figure 7. Effect of GppNHp on the affinity of sCCK-8 as an inhibitor of ${ }^{3} \mathrm{H}-\mathrm{L}-364,718$ binding to rat brain membranes. Freshly prepared membranes were incubated for 60 min with ${ }^{3} \mathrm{H}-\mathrm{L}-364,718$ and a range of concentrations of sCCK- 8 in the absence (open symbols) and presence (closed symbols) of $100 \mu \mathrm{M}$ GppNHp. Nonspecific binding was defined by $1 \mu \mathrm{M} \mathrm{L}-365,031$. The inclusion of the guanyl nucleotide in the incubation medium had no effect on the binding of ${ }^{3} \mathrm{H}-364,718$ itself but reduced the affinity of SCCK-8 for the receptor sites approximately 10 fold. Additionally, the Hill slope was raised to near unity. Data are the mean values from 3 separate experiments.

(Fig. 7). Furthermore, the Hill slope increased from $0.5 \pm 0.06$ to $0.9 \pm 0.17$ in the presence of the nucleotide.

\section{Discussion}

We have shown that, in discrete areas of rat brain, there exist CCK receptors that are sensitive to compounds having high affinity and selectivity for peripheral CCK receptors. A clear distinction between receptors for CCK present in the IPN and also the AP-NTS complex and those located in most other areas of the brain is the high affinity shown by AP, IPN, and NTS sites for the nonpeptide antagonists L-365,031 and L-364,718. The present work therefore confirms and enlarges upon the original observations of Moran et al. (1986). These authors reported that binding of ${ }^{125}$ I-CCK-33 in the AP-NTS, IPN, and also posterior hypothalamic nuclei was less sensitive to inhibition by desulfated $C C K$ than binding in the cerebral cortex, a pattern similar to that seen with ${ }^{125} \mathrm{I}-\mathrm{CCK}$-binding to pancreatic membranes (Innis and Snyder, 1980). However, subclassification of peptide hormone receptors according to differences in the affinity of peptides with fairly limited degrees of selectivity is problematic, especially in view of the susceptibility of peptides to endogenous metabolic enzymes. The use of nonpeptide antagonists having high degrees of selectivity provides a much better basis upon which to classify receptor subtypes, both within and without the CNS. The close agreement between the affinity of $\mathrm{L}-365,031$ for $\mathrm{CCK}$ receptors in the pancreas and those in the AP-NTS complex, together with the direct labeling of the brain receptors with ${ }^{3} \mathrm{H}-\mathrm{L}-364,718$, is reconcilable only with the fact that the receptors in these areas are truly of the peripheral type, termed CCK-A or alimentary receptors by Moran and colleagues. In fact, the pharmacological profile of compounds inhibiting ${ }^{3} \mathrm{H}-\mathrm{L}-364,718$ binding to membranes prepared from the discrete brain areas is very similar to that reported using pancreatic membranes and ${ }^{125}$ I-CCK (Sankaran et al., 1979; Innis and Snyder, 1980; Steigerwalt and Williams, 1981; Williams et al., 1986) or ${ }^{3} \mathrm{H}-\mathrm{L}-364,718$ (Chang et al., 1986a).

The localization of L-365,031-sensitive ${ }^{125}$ I-CCK binding and of ${ }^{3} \mathrm{H}-\mathrm{L}-364,718$ itself were identical in the areas examined. ${ }^{3} \mathrm{H}$ -

\begin{tabular}{lc}
$\begin{array}{l}\text { Table 1. pIC } \\
\text { homogenates of AP, NTS, and IPN } \\
\text { homes for inhibition of }{ }^{3} \mathrm{H}-\mathrm{L}-364,718 \text { binding to } \\
\text { Compound }\end{array}$ & $\mathrm{pIC}_{50} \pm \mathrm{SEM}$ \\
\hline sCCK-8 & $7.8 \pm 0.08$ \\
L-365,031 & $7.9 \pm 0.30$ \\
dCCK-8 & $5.7 \pm 0.06$ \\
Ceurulein & $7.4 \pm 0.20$ \\
(S)Tifluadom & $7.3 \pm 0.26$ \\
(R)Tifluadom & $6.6 \pm 0.30$ \\
CCK-6 & $<4.0$ \\
CCK-4 & $<4.0$ \\
Gastrin & $<4.0$
\end{tabular}

Membrane fractions were prepared from freshly dissected area postrema (AP), nucleus tractus solitarius (NTS), and interpeduncular nucleus (IPN). These were incubated with $0.2-0.3 \mathrm{nM}{ }^{3} \mathrm{H}-\mathrm{L}-364,718$ either alone or in the presence of a range of test compound. Nonspecific binding was measured using $1 \mu \mathrm{M}$ L-365,031 and was subtracted from total binding to give the specific portion. Values are geometric means \pm SEM of the negative logarithm of the molar concentration producing $50 \%$ inhibition of specific binding from between 3 and 6 separate experiments.

L-364,718 may therefore be considered the ligand of choice for imaging these receptor sites, especially in view of the good definition given by tritium in autoradiographic experiments. However, by using both ${ }^{125} \mathrm{I}-\mathrm{CCK}$ and displacing with "cold" antagonist, as well as labeling directly with ${ }^{3} \mathrm{H}-\mathrm{L}-364,718$, complementary information concerning the relative distribution of "central" and "peripheral" sites was obtained, even within a narrowly defined anatomical region such as the AP-NTS complex. Thus, the occlusion of "A" sites in certain parts of the NTS allowed detection of a binding that was of the type usually found within the CNS-high affinity for dCCK and low affinity for $\mathrm{L}-364,718$ or $\mathrm{L}-365,031$ (CCK-B receptor). Conversely, direct labeling with ${ }^{3} \mathrm{H}-\mathrm{L}-364,718$ allowed the localization of "A" sites to be made in an uncompromised fashion, and the results strongly suggest that regional densities of binding within the NTS vary from the medial to lateral portions of the nucleus. Such variations in binding density within the nucleus may be associated with afferent input via the vagus from a particular anatomical region (Berger, 1979; Kalia and Mesulam, 1980; Higgins and Schwaber, 1981; Leslie et al., 1982). Nonetheless, the highest density of CCK-A sites was found in regions of the area postrema. Perhaps this is not totally surprising in view of the afferent vagal input to the area from peripheral organs such as the stomach (Leslie et al., 1982) and the high CCK content of the vagus itself (Dockray et al., 1980; Palkovitz et al., 1982). Visualization of the projections of the vagus into the AP and NTS using HRP (Kalia and Sullivan, 1982) parallels the distribution of ${ }^{3} \mathrm{H}-\mathrm{L}-364,718$ binding in this area, suggesting the involvement of $\mathrm{CCK}-\mathrm{A}$ receptors in the processing of afferent information within this nucleus. Indeed, sulfated CCK-8 administered peripherally or directly to the NTS has been shown to have profound effects on both cardiovascular and respiratory function in the cat, effects not mimicked by compounds with low affinity for the CCK-A sites, for example, CCK-4 and desulfated CCK (Denavit-Saubie et al., 1985). Furthermore, sCCK-8 (but not dCCK) has been shown to inhibit respiratory neurons in the NTS (Morin et al., 1983), which again suggests the involvement of CCK-A receptors.

Why peripheral type receptors should be present in other areas such as the IPN is unclear, as, in contrast to the $\Lambda P$, the IPN is located well within the blood-brain barrier. CCK-like im- 
munoreactivity is present in cell bodies located on the rostral margins of the nucleus, and dense networks of fiber plexi, which also show CCK-like immunoreactivity, can be detected surrounding the IPN (Kubota et al., 1983; Hamill et al., 1984). However, the density of these is much less within the nucleus itself. Despite that the exact function of the IPN remains unclear, it is probable that if released from fibers around the IPN, CCK would act at A-type CCK receptors.

Finally, the sensitivity to guanyl nucleotide shown by CCK-A receptors in AP, NTS, and IPN is another feature shared with their peripheral counterparts (Innis and Snyder, 1980). This modulation of agonist, but not of antagonist, binding by $\mathrm{GppNHp}$ reflects the linkage of the receptor to one of a series of GTPbinding proteins (see Rodbell, 1980) and the ability to form a ternary complex when activated. Pancreatic receptors stimulate phosphoinositol (PI) turnover (Hokin-Neaverson and Sadeghian, 1984; Lin et al., 1986) and have also been shown to stimulate adenylate cyclase (Svoboda et al., 1976), although PI metabolism is more likely to be linked to enzyme secretion. CCK-B receptors may also be linked to a GTP-binding protein in a similar way (Innis and Snyder, 1980; but see Van Dijk et al., 1984), yet they do not appear to be linked to a second messenger, as neither PI turnover nor adenylate cyclase is stimulated. Clearly, one intriguing question for the future is whether brain CCK-A receptors are linked to PI turnover or cyclase or whether, like their more ubiquitous CNS counterparts, they are linked to a G-protein other than Gs, Gi, or Gp.

In conclusion, the present work demonstrates the existence of subtypes of CCK receptors within the rat CNS that are sensitive to nonpeptide compounds previously shown to have high affinity and selectivity for pancreatic CCK receptors. These receptors have been further characterized by binding studies using membranes prepared from the AP-NTS complex and IPN using ${ }^{3} \mathrm{H}-\mathrm{L}-364,718$; the pharmacological specificity of brain sites labeled with this radioligand is similar to that seen in the pancreas. The determination of the function of such receptors within the brain awaits further study, but this should be facilitated by the use of nonpeptide antagonists that are selective for CCK-A receptors present in periphery and CNS.

\section{References}

Berger, A. J. (1979) Distribution of carotid sinus nerve afferent fibres to solitary tract nuclei of the cat using transganglionic transport of horseradish peroxidase. Neurosci. Lett. 36: 37-42.

Chang, R. S. L., and V. J. Lotti (1986) Biochemical and pharmacological characterization of an extremely potent and selective nonpeptide cholecystokinin antagonist. Proc. Natl. Acad. Sci. USA 83: 4923-4926.

Chang, R. S. L., V. J. Lotti, T. B. Chen, and K. A. Kunkel (1986a) Characterization of binding of ${ }^{3} \mathrm{H}-\mathrm{L}-364,718$. A new potent nonpeptide cholecystokinin anlagonist for peripheral receptors. Mol. Pharmacol. 30: 212-217.

Chang, R. S. L., V. J. Lotti, T. B. Chen, and M. E. Keegan (1986b) Titluadom, a kappa opiate agonist, acts as a peripheral cholecystokinin receptor antagonist. Neurosci. Lett. 72: 211-214.

Clark, C. R., and M. D. Hall (1986) Hormone receptor autoradiography: Recent developments. Trends Biochem. Sci. 11: 195-199.

Crawley, J. N. (1985) Comparative distribution of cholecystokinin and other neuropeptides: Why is this neuropeptide different from all other neuropeptides? Ann. NY Acad. Sci. 448: 1-8.

Denavit-Saubie, M., M. Hurle, M. P. Morin-Sarun, A. S. Foutz, and J. Champagnat (1985) The effects of cholecystokinin-8 in the nucleus tractus solitarius. Ann. NY Acad. Sci. 448: 375-384.

Dockray, G. J. (1976) Immunochemical evidence of cholecystokininlike peptides in brain. Nature 264: 568-570.

Dockray, G. J., R. A. Gregory, H. J. Tracy, and W. Y. Zhu (1980)
Transport of cholecystokinin octopeptide-like immunoreactivity toward the gut in afferent vagal fibres in cat and dog. J. Physiol. (Lond.) 314: $501-511$.

Evans, B. E., M. G. Bock., K. E. Rittle, R. M. Dipard, W. L. Whitter, D. F. Veber, P. S. Anderson, and R. M. Freidinger (1986) Design of potent, orally effective, nonpeptidal antagonists of the peptide hormone cholecystokinin. Proc. Natl. Acad. Sci. USA 83: 4918-4922.

Greenwood, R. S., S. E. Godar, T. A. Reaves, and J. N. Hayward (1981) Cholecystokinin in hippocampal pathways. J. Comp. Neurol. 203: 335-350.

Hamill, G. S., J. A. Olschowka, N. J. Lenn, and D. A. Jacobowitz (1984) The subnuclear distribution of substance $P$, cholecystokinin, vasoactive intestinal peptide, somatostatin, Leu-enkephalin, dopamine$\beta$-hydroxylase and serotonin in the rat interpeduncular nucleus. $\mathbf{J}$. Comp. Neurol. 226: 580-596.

Higgins, G. A., and J. S. Schwaber (1981) Afferent organization of the nucleus tractus solitarius of the rabbit: Evidence for overlap of forebrain and primary afferent inputs. Anat. Rec. 199: 144a.

Hökfelt, T., J. F. Rehfeld, I. Skirboll, B. Ivemark, M. Goldstein, and K. Markey (1980) Evidence for co-existence of dopamine and cholecystokinin in meso-limbic neurons. Nature 285: 476-478.

Hokin-Neaverson, M., and K. Sadeghian (1984) Lithium induced accumulation of inositol-phosphate during cholecystokinin octapeptide and acetylcholine stimulated phosphatidylinositol breakdown in dispersed mouse pancreas acinar cells. J. Biol. Chem. 259: 4346-4352.

Innis, R. B., and S. Snyder (1980) Distinct cholecystokinin receptors in brain and pancreas. Proc. Natl. Acad. Sci. USA 77: 6917-6921.

Innis, R. B., F. M. A. Correa, G. R. Uhl, B. Schreider, and S. H. Snyder (1979) Cholecystokinin octapeptide immunoreactivity: Histochemical localization in rat brain. Proc. Natl. Acad. Sci. USA 76: 521535.

Kalia, M., and M.-M. Mesulam (1980) Brain stem projections of sensory and motor components of the vagus complex in the rat. II. Laryngeal, tracheobronchial, pulmonary, cardiac and gastrointestinal branches. J. Comp. Neurol. 193: 467-503.

Kalia, M., and J. M. Sullivan (1982) Brainstem projections of sensory and motor components of the vagus nerve in the rat. J. Comp. Neurol. 211: $248-264$.

Kubota, Y., S. Inagaki, S. Shiosaka, H. J. Cho, K. Tateishu, E. Hashimura, T. Hamaoka, and M. Tohyama (1983) The distribution of cholecystokinin octapeptide-like structures in the lower brain stem of the rat: An immunohistochemical analysis. Neuroscience 9: 587604.

Leslie, R. A., D. G. Gwyn, and D. A. Hopkins (1982) The central distribution of the cervical vagus nerve and gastric afferent and efferent projections in the rat. Brain Res. Bull. 8: 37-43.

Lin, C. W., B. R. Bianchi, D. Grant, T. Miller, E. A. Danaher, M. D. Tufano, H. Kopecka, and A. M. Nadzen (1986) Cholecystokinin receptors: Relationships among phosphoinositide breakdown, amylase release and receptor affinity in pancreas. J. Pharmacol. Exp. Ther. 236: 729-734.

Moran, T. H., P. Robinson, M. S. Goldrich, and P. McHugh (1986) Two brain cholecystokinin receptors: Implications for behavioural actions. Brain Res. 362: 175-179.

Morin, M. P., P. DeMarchi, J. Champagnat, J.-J. Vanderhaeghen, J. Rossier, and M. Denarit-Saubie (1983) Inhibitory effects of cholecystokinin octapeptide on neurons in the nucleus tractus solitarius. Brain Res. 265: 333-338.

Palkovitz, M. J., Z. Kiss, M. C. Benfield, and T. H. Williams (1982) Cholecystokinin in the solitary tract of the rat: Evidence for its vagal origin. Brain Res. 252: 386-390.

Paxinos, G., and C. Watson (1982) The Rat Brain in Stereotoxic Coordinates, Academic, New York.

Rodbell, M. (1980) The role of hormone receptors and GTP regulatory proteins in membrane transduction. Nature 284: 17-22.

Saito, A., H. Sankaran, I. D. Goldrine, and J. A. Williams (1980) Cholecystokinin receptors in the brain: Characterization and distribution. Science 208: 1155-1156.

Sankaran, H., C. W. Deveney, I. D. Goldfine, and J. A. Williams (1979) Preparation of biologically active radioiodinated cholecystokinin for radioreceptor assay and radioimmunoassay. J. Biol. Chem. 254:93499351 .

Steigerwalt, R. W., and J. A. Williams (1981) Characterization of cholecystokinin receptors on rat pancrcatic membrancs. Endocrinology 109: 1746-1753. 
Svoboda, M., P. Robberecht, J. Camus, M. Deschodt-Lanckman, and J. Christophe (1976) Subcellular distribution and response to gastrointestinal hormones of adenylate cyclase in the rat pancreas. Eur. J. Biochem. 69: 185-193.

Vanderhaeghen, J.-J., F. Lotstra, J. DeMey, and C. Gilkes (1980) Immunohistochemical localization of cholecystokinin- and gastrin-like peptides in the brain and hypophysis of the rat. Proc. Natl. Acad. Sci. USA 77: 1190-1194.

Vanderhaeghen J.-J., F. Lostra, G. Vierendeels, C. Gilkes, C. Deschepper, and P. Verbanck (1981) Cholecystokinin in the central nervous system and neurohypophysis. Peptides 2: 81-88.
Vanderhaeghen, J.-J., J. C. Signcau, and W. Gepts (1975) New peptide in vertebrate CNS reacting with antigastrin antibodies. Nature 257 : 604-605.

Van Dijk, A., J. G. Richards, A. Trzeciak, D. Gillessen, and H. Mohler (1984) Cholecystokinin receptors: Biochemical demonstrations and autoradiographical localization in rat brain and pancreas using ${ }^{3} \mathrm{H}$ cholecystokinin as radioligand. J. Neurosci. 4: 1021-1033.

Williams, J. A., S. R. Vigna, C. Sakamoto, and I. D. Goldfine (1986) Brain cholecystokinin receptors. Ann. NY Acad. Sci. 448: 220-230. 